\title{
Őrtilos - Zrínyi-Újvár kútjából származó famaradványok dendrokronológiai vizsgálata
}

\author{
GRYNAEUS ANDRÁS \\ Magyar Dendrokronológiai Laboratórium - Cincér Bt., 1021 Budapest, Széher út 76/a., \\ e-mail: dendro@ludens.elte.hu
}

GRYNAEUS, A.: Dendrochronological study of well from Örtilos - Zrínyi-Újvár.

Abstract: In Summer 2017, a well was unearthed at the archaeological site within the boundaries of Örtilos, identified as Zrínyi Újvár. Archaeologists hoped that the dendrochronological analysis of the wooden remains would provide an exact dating of the site. Furthermore, they expected data for to decide whether there was an earlier fortification there and whether that could be considered as the predecessor of Zrínyi Újvár. Dendrochronological analysis included 23 samples, most of them coming from young and often injured trees. The used material was mainly pedunculate oak, a smaller part of the samples was made either of sessile oak, or of spruce. Eight samples could be dated leading to the conclusion that the material of the well was cut not earlier than in 1658 .

Keywords: dendrochronology, Dating, woodkonstruction

\section{Bevezetés}

Az Örtilos határában a Zrínyi Újvárral / Új-Zrínyivárral azonosított lelőhely területén 2017 nyarán feltárt kút faanyagának dendrokronológiai elemzésétől a szakemberek a lelőhely pontos keltezését várták, és annak a kérdésnek az eldöntéséhez reméltek adatokat, hogy létezett-e előzménye a várnak, illetve valóban itt volt-e az előzménynek tekinthető erődítmény.

\section{Anyag és módszer}

A dendrokronológia a régészet egyik természettudományos alapú segédtudománya, amely a famaradványok korát tudja meghatározni nagy (igen optimális esetben akár negyedév) pontossággal, a fákban megőrződött évgyűrűk segítségével. Az elemzésekhez a feltárás befejezése után, a helyszínen fürészeltük ki a szükséges teljes keresztmetszetű mintákat (1. ábra).

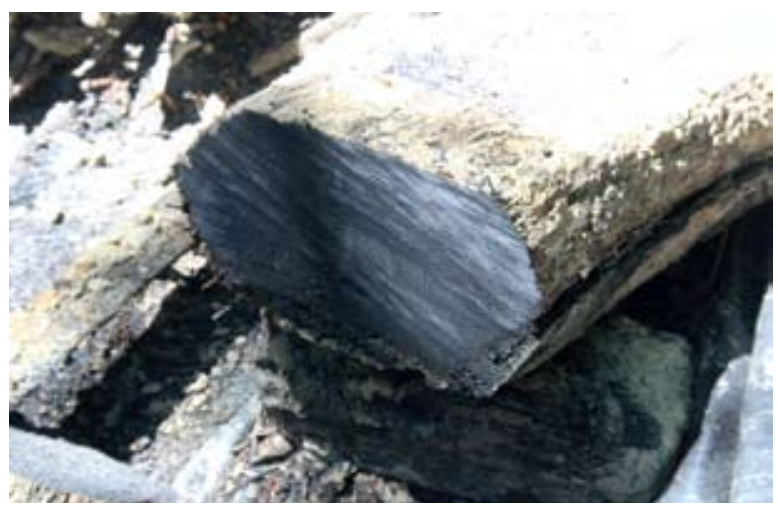

1. ábra. Gerendavég a minta lefürészelése után
A minták állapota, megtartása jó volt, érdemi károsodás, korhadás nem nehezítette az elemzéseket. Ugyanakkor több mintán égésnyomok, a külső farészek szenülése volt megfigyelhető (2. ábra).

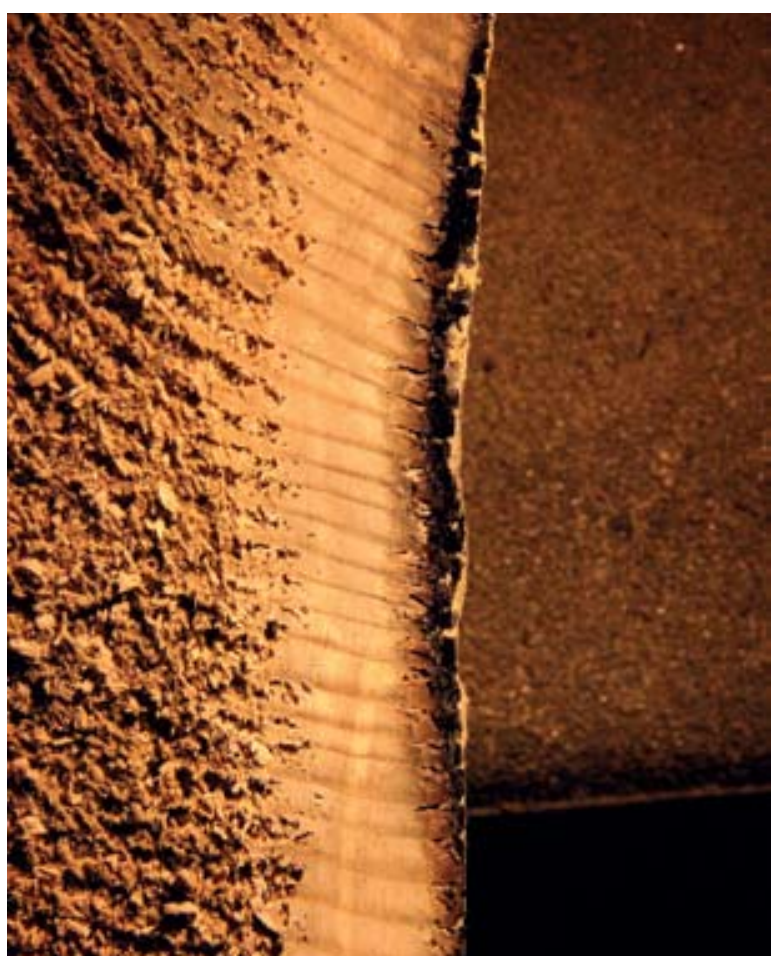

2. ábra. Égésnyomok a 18. mintát biztositó lucfenyő deszkán

A mintákon két vizsgálatot végeztünk el: először sztereo-binokuláris mikroszkóp 18-szoros nagyítása mellett a xylotómiai elemzést, azaz fafajmeghatározást végeztünk, majd ezt követte a dendrokronológiai elemzés.

\section{Xylotómiai vizsgálat eredményei}

A xylotómiai vizsgálat, azaz a fafajmeghatározás során megállapíthattuk, hogy a minták elsöprő többségében a tölgyfélékre jellemző szöveti szerkezetet találtunk: gyűrűslikacsú szöveti szerkezetben, a szállítónyalábok szélesebb évgyűrükben lángnyelv alakban elvékonyodnak. Ugyanakkor a minták nagy részében (2., 3., 5., 6., 7., 9., 10., 11., 12., 15., 16., 17. és 19. minta) a nagyméretű szállító-edények a tavaszi pásztában következetesen csak egy-két sorban helyezkedtek el (3. és 4. ábra). 

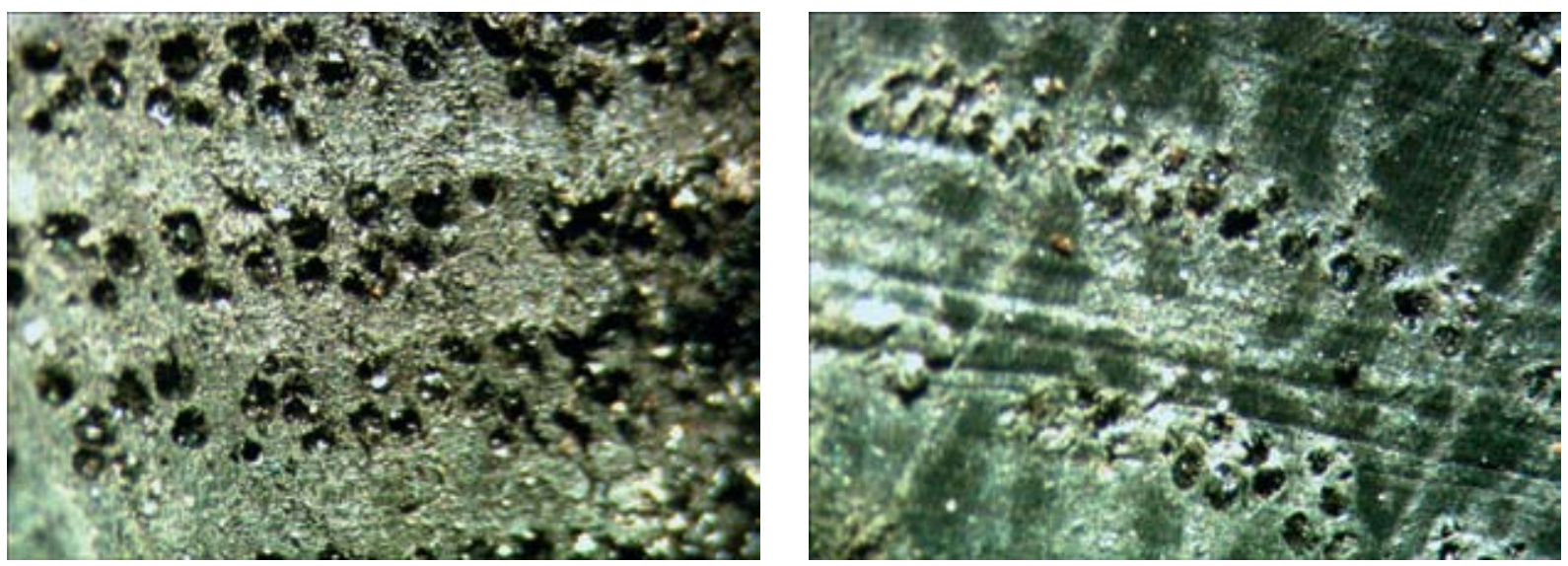

3-4. ábra. A 2. és 9. minta szöveti képe 18-szoros nagyítású keresztmetszeti felvételen

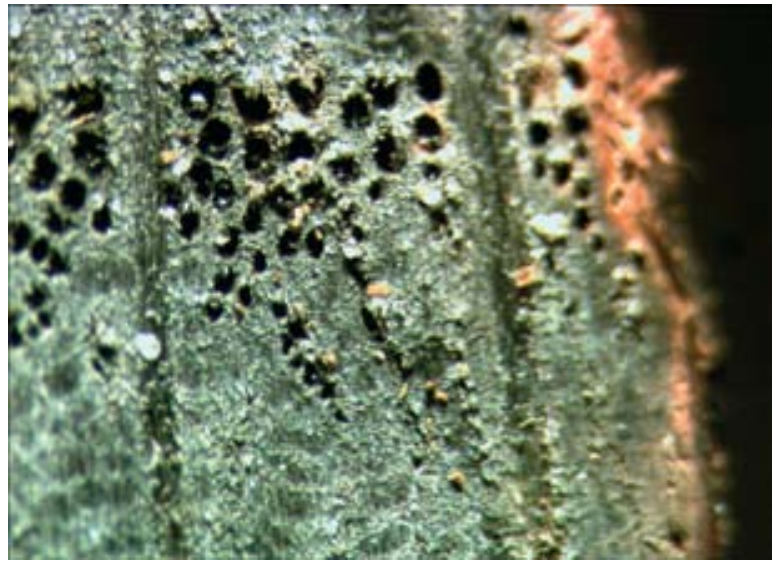

5. ábra. A 14. minta szöveti képe 18 szoros nagyítású keresztmetszeti felvételen

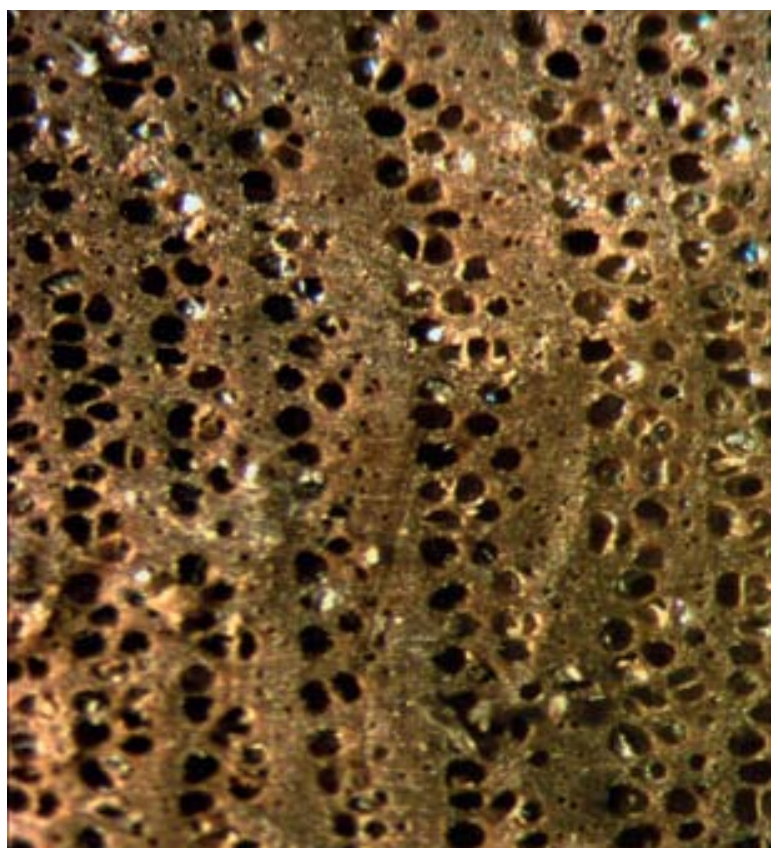

7. ábra. A 23. minta szöveti képe 18 szoros nagyitású keresztmetszeti felvételen

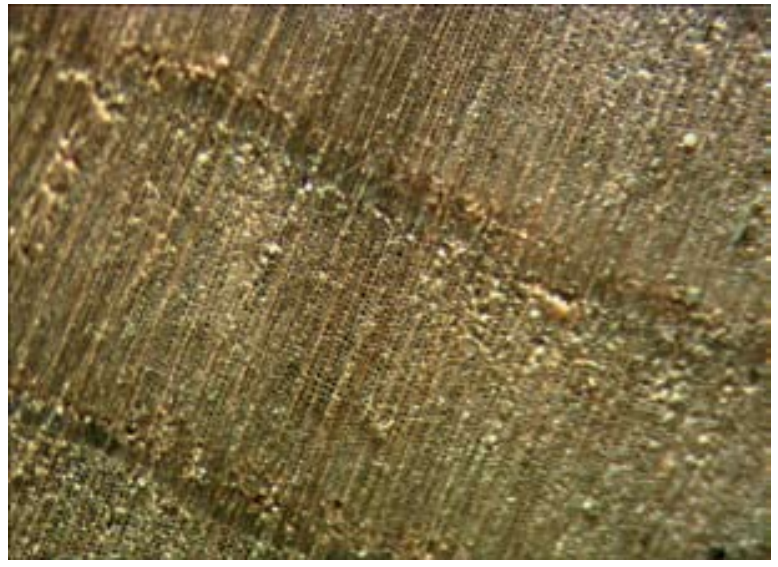

6. ábra. A 18. minta szöveti képe 18 szoros nagyítású keresztmetszeti felvételen

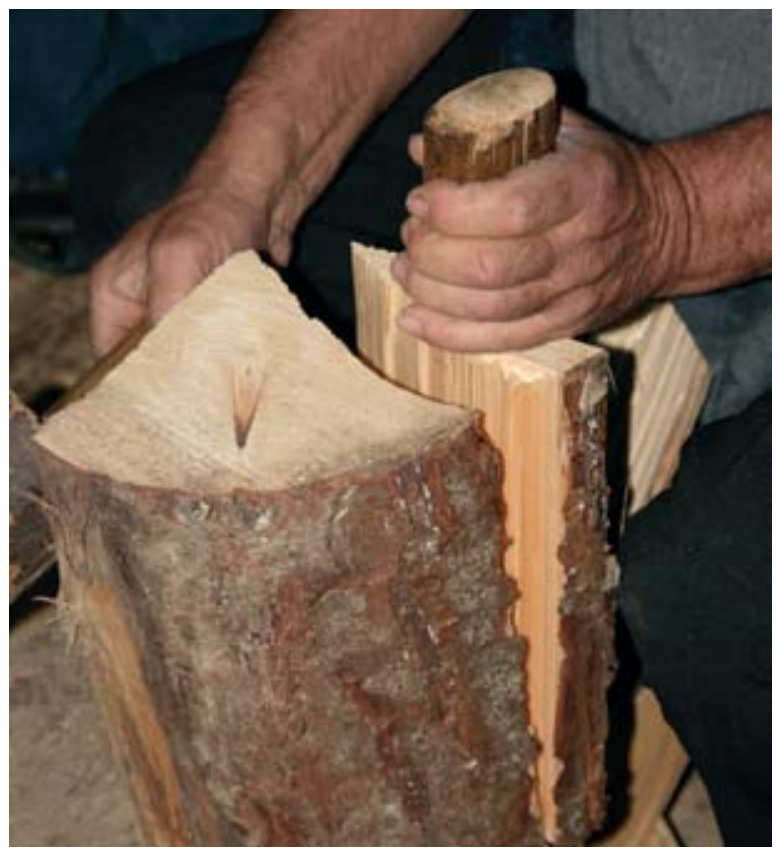

8. ábra. Zsindely-alapanyag kihasítása egy fenyőrönkből recens felvételen 
Elfogadva néhai Babos Károly meghatározását ${ }^{1}$, e jegyek alapján fafaját a kocsányos tölggyel (Quercus robur L.) azonosítottuk.

Ugyanakkor a minták egy másik részében (1., 4., 8., 13. és 14. minta) a nagyméretű szállító-edények a tavaszi pásztában következetesen több sorban helyezkedtek el (5. ábra).

Ismét elfogadva Babos Károly meghatározását, e jegyek alapján fafaját a szárazságtürő kocsánytalan tölggyel (Quercus petraea (Mattuschka) Lieblein.) azonosítottuk.

Az eddigi kutatások fényében általánosságban megállapíthatjuk, hogy a tölgyfélék használata az újkor előtt tipikusnak mondható Magyarország területén, és nem számít rendkívülinek a település földrajzi helyzete révén sem. Ugyanakkor a kétféle tölgyváltozat vegyes használata jelzi, hogy nem egy zárt, gondozott állományból származnak a felhasznált fák, hanem nagyobb területről. Mivel a lelőhely a Zalai-dombság (ahol a természetes erdőalkotó tölgyfaj a kocsánytalan tölgy) és a Dráva-ártér (mely természetes tölgyfaja a kocsányos tölgy) határán fekszik, nem meglepő ez a megfigyelés ${ }^{2}$.

A minták között néhány fenyőfából kialakított deszka illetve gerenda is volt. E minták szöveti képének jellegzetessége, hogy nincsenek gyantajáratok benne és a késői pászta a legtöbb esetben keskeny volt (6. ábra).

Ezen szöveti jegyek alapján a faanyag faját a lucfenyővel (Picea abies (L.) Karst.) azonosítottuk.

Az eddigi kutatások eredményei alapján a fenyőfélék épületfaként való használata az újkorra jellemző, a korábbi korszakok magyarországi ásatásainak anyagában alig fordul elő. Az ország belső területén - ismereteink szerint - nem volt érdemi fenyőállomány, így távolabbi területekről, vélhetően az Alpok térségéből szállíthatták ide a faanyagot. A Dráva folyó közelsége miatt ez nem okozhatott komolyabb nehézséget.

A 23. minta, az egyik csapoláshoz használt fa alapanyaga eltért az eddigiektől. Gyűrüslikacsú fafajt használtak hozzá (7. ábra), de nem tölgyfélét, hanem kőrist (Fraxinus sp.)

E fafaj előfordulása a térség növényvilágának ismeretében ismét nem meglepő, ugyanis a Dráva-ártér természetes kőrisfaja a magyar kőris (Fraxinus angustifolia ssp. pannonica), így vélhetően ezt a fafajt használták fel a kút készítésekor.

\section{Technikai megfigyelések}

Egyetlen mintán sem találtunk kéregmaradványt. A tölgymintákon szijácshoz tartozó évgyürüket sem sikerült azonosítani. E két megfigyelés jelzi, hogy a kút készítői igényes munkát végeztek. A sérülékeny és a kút tartósságát negatívan befolyásoló farészeket a felhasználás előtt eltávolították a fatörzsekröl.

1 Babos 1994

2 A helyi növényföldrajzi sajátságok értelmezéséhez Dr. Juhász Magdolnától (Rippl-Rónai Múzeum - Kaposvár) kaptam értékes segítséget, melyet ezúton is köszönök!
A felhasznált (és megvizsgált) faanyag minőségére jellemző volt, hogy sok a sérült évgyürüszerkezetü, torzult növekedésủ fa közöttük. Ez jelzi, hogy a kút készítői valamilyen okból nem tudtak/akartak minőségi faanyagot beépíteni, „beérték” (vagy beérni kényszerültek) a gyengébb minőségűvel.

Kialakítás szempontjából több csoportba oszthatók a maradványok: vannak négyzetesre lebárdoltak (1., 2., 5., 8., 10., 11., 13., 14., 15., 16. és 17. minta), csak részben lebárdolt (6. és 9 . minta), rönknek meghagyott ( 7 . minta) és deszkának kialakított példányok (3., 4., 12. és 18. minta) egyaránt. Speciális a 19. minta esete. Ez a 3 darab maradvány egyértelműen zsindelyből származik. Ezek kialakítása sajátos: a néprajzi, illetve recens anyagon, valamint az eddig megvizsgált középkori/koraújkori régészeti ásatásokon előkerült ilyen maradványokon ${ }^{3}$ megfigyeltektől két ponton eltér. Egyrészt vegyes fafelhasználás jellemzi: az általánosnak mondható fenyő mellett tölgyből készült zsindelyt is használtak. Másrészt a kialakításuk is sajátos, míg a megvizsgált tölgyzsindelyt a ma is megfigyelhető módon sugárirányban hasították ki a rönkökből, addig a fenyőket nem szabályos sugárirányban, hanem pontatlanul dolgozva, vagy szándékosan érintő irányba (8. ábra).

Ez az anyaghasználatban és kialakításmódban megfigyelt jellegzetesség arra utal, hogy ezek kialakítására nem figyeltek oda, hevenyészve vagy nem megfelelő felkészültséggel, gyakorlattal rendelkező személyek végezték azt.

A leletanyag lehetővé tette a gerendák összeerösítésére használt csapok vizsgálatát is. Ezekre, mint láttuk vegyes fafelhasználás volt a jellemző: lucfenyő és kőris egyaránt elöfordul köztük. Másrészt kiderült, hogy ezeket a szabályos kör keresztmetszetű elemeket nagy fatörzsekből faragták/esztergályozták ki, így például a 23. minta 49 darab évgyürüt tartalmazott a kb. 8 centiméteres átmérője ellenére!

\section{Dendrokronológiai elemzés}

A dendrokronológiai elemzés során a mintákon (néhány kivételtől eltekintve) több sugár mentén mértük le az évgyürük vastagságát és ezeket az értékeket átlagoltuk.

A minták többségére az alacsony (60 db körüli) évgyürüszám volt a jellemző. Ez egyrészt jelzi, hogy az építők nem a legjobb minőségü, idős állományból származó faanyagot használtak fel. Másrészt jelzi, hogy az adott pillanatban a felhasználás fontosabb szempont volt az erdőgazdálkodás gazdaságossági szempontjainál, hisz a tölgyeket a mai erdészeti gyakorlat szerint 90-120 éves korukban „éri meg” kivágni. Írott és képi forrásokból tudjuk, hogy már a középkorban törekedtek a tudatos erdőgazdálkodásra, és felhasználás szempontjából többféle erdőt különítettek el. Ugyanakkor a források azt is megmutatják, hogy a török háborúk idején az amúgy is magas fafogyasztás megugrott, és

3 Például az Eger - Dobó tér-i ásatás egyik kútjából kerültek elő hasonló korú zsindelyek, melyek valószínüleg ugyanígy a kútházhoz tartoztak. 
a korábbi tudatos(abb) gazdálkodás fenntartására már nem volt lehetőség. Az viszont a kutatás jelen állásánál vitatott, hogy ez milyen mértékű változást okozott a Kárpát-medencei erdőállományban ${ }^{4}$.

$\mathrm{Az}$ adatsorok rövidsége megnehezítette a mintaanyag datálását. Michael Grabner (Universität Wien) nagyszámú osztrák régészeti és műemléki faanyagon végzett statisztikai elemzéséből tudjuk, hogy a 40 évgyürünél kevesebbet tartalmazó adatsorok esetében a minták $60 \%$-át nem sikerül keltezni. Az évgyürük számának növekedésével a sikeres keltezés aránya meredeken emelkedik.

Az évgyürük átlagos évgyürűvastagsága nagy volt, ami jelzi, hogy a felhasznált fák jó körülmények között, számukra kedvező élőhelyen növekedtek a kivágásukig.

Az elemzések fontos megállapítása volt, hogy annak ellenére, hogy a gerendáknak és a zsindely-deszkáknak „Szép”, egyenletes növekedésü és jól mérhető évgyürűi voltak, évgyürüszerkezetük alig hasonlított egymásra, így megbízhatóan átlagolt adatsorokat nem sikerült készíteni. Ez elsősorban az alacsony évgyürüszámmal, azaz a felhasznált faanyag fiatal életkorával és a jó élöhellyel magyarázható. Hisz a kedvező életkörülmények között élő fiatal egyedek rövid életük nagy részében a növekedésre tudtak koncentrálni, és a külső tényezők, pl. az időjárás, ebben csak kicsit zavarták őket.

Ezért az egyedi adatsorokat vetettük össze a térségre érvényesnek tűnő kronológiákkal (magyar alapadatsor, szlovén adatsorok, osztrák adatsorok). Több esetben érdemi egyezéseket találtunk, és ezeket két minőségi kategóriába soroltuk: amelyek több kronológia esetén is azonos keltezési eredményt adtak azokat valószínünek vettük, amelyek csak egy-két adatsor alapján tűntek keltezhetőknek, azokat kicsit valószínünek. Így a keltezés minősítése jó és gyenge lehetett. A szijácsévgyürük hiányában az utolsó, a minta külső szélén megtalált legfiatalabb évgyürü keletkezési évéhez hozzá kell adni a szijácsévgyürük minimális számát, azaz 12 évet, és így kaptuk meg a szóba jöhető legkorábbi kivágási időpontot (1. táblázat).
1. táblázat. A keltezett gerendák

\begin{tabular}{|c|c|c|c|}
\hline $\begin{array}{c}\text { minta } \\
\text { száma }\end{array}$ & $\begin{array}{c}\text { utolsó évgyúrú } \\
\text { keletkezési éve }\end{array}$ & $\begin{array}{c}\text { legkorábbi } \\
\text { kivágási } \\
\text { időpont }\end{array}$ & $\begin{array}{c}\text { keltezés } \\
\text { minősége }\end{array}$ \\
\hline $2 \mathrm{~s}$ & 1645 & 1657 & jó \\
\hline $7 \mathrm{a}$ & 1593 & 1615 & gyenge \\
\hline $10 \mathrm{~b}$ & 1618 & 1630 & gyenge \\
\hline $11 \mathrm{a}$ & 1640 & 1652 & jó \\
\hline $13 a$ & 1646 & 1658 & gyenge \\
\hline $15 \mathrm{~s}$ & 1640 & 1652 & jó \\
\hline $17 \mathrm{~s}$ & 1645 & 1657 & jó \\
\hline $18 \mathrm{~s}$ & 1653 & 1653 & jó \\
\hline
\end{tabular}

\section{Összegzés}

Mivel a hosszabb adatsorok (15, 17, 18. minta) egyértelműen hasonló keltezési eredményt adtak, illetve az egyik ilyen adatsor (18. minta) fafaja eltérő is volt, nagy valószínűséggel állíthatjuk, hogy az objektum anyagát 1658 után vágták ki és használták fel a kút megépítéséhez.

Az égett és nem égett fák között nem sikerült érdemi korkülönbséget rögzíteni, így nagy valószínűséggel ugyanannak, vagy egy ugyanakkor épített szerkezetnek a részei. A leglogikusabb magyarázat szerint ezek a megégett gerendák a kútház anyagához tartozhattak, azaz a kút szerkezete és a kútház faanyagának kivágási időpontja között nincs érdemi eltérés.

\section{Irodalom}

BABOS K. 1994: Fafajmeghatározás restaurátorok számára. - Magyar Nemzeti Múzeum, Budapest
GRYNAEUS A. 2015: Miről mesélnek a régi fák évgyűrűi? (Régészet, dendrokronológia, klíma-történet). - Archaeolingua, Budapest

4 A kérdésröl részletesebben lásd: Grynaeus 2015, Hogyan vágták ki eleink a fákat? Egy kis erdőgazdálkodás-történet című fejezetét (pp.163) 